\title{
Sarcomatoid Intrahepatic Cholangiocarcinoma
}

National Cancer Institute

\section{Source}

National Cancer Institute. Sarcomatoid Intrahepatic Cholangiocarcinoma. NCI

Thesaurus. Code C41620.

A rare, aggressive variant of intrahepatic cholang iocarcinoma. It is characterized by the presence of adenocarcinoma cells that are interming led with malignant pleomorphic spindle cells. 